\title{
Evaluation of E-Learning Web-Portal (e-HearMe) Designed for Hearing-Impaired Learners
}

\author{
Norazah Nordin ${ }^{1}$ \\ Melor Md Yunus 1 \\ Rozniza Zaharudin 1 \\ Hadi Salehi $2^{\star}$ \\ Mohd Hanafi Mohd Yasin ${ }^{1}$ \\ Mohamed Amin Embi ${ }^{1}$ \\ ${ }^{1}$ Faculty of Education, Universiti Kebangsaan Malaysia (UKM), Malaysia \\ ${ }^{2}$ Faculty of Humanities, Najafabad Branch, Islamic Azad University, Najafabad, Isfahan, Iran \\ Corresponding Author Email: hadisalehi1358@yahoo.com
}

Doi:10.5901/mjss.2015.v6n4s1p248

\begin{abstract}
E-Learning is the use of electronic educational technology in learning and teaching, where there is no face-to-face interaction as advanced online learning is held in virtual learning atmospheres. Learning Information Communication Technology (ICT) is crucial in the Hearing-Impaired Education Development as the visual display plays an important role in helping hearingimpaired learners understand a task. The objective of this research is to implement and evaluate the ICT education courses constructed from the E-Learning Portal developed based on their knowledge and attitude in using the Web-Portal. To achive the aim of the study, the research locations were chosen from 3 schools performing the Hearing-Impaired Education Program in Malaysia. By doing so, 72 Hearing-Impaired Students were chosen from Form 4 and Form 5 of the Secondary Level as the research sample. In the evaluation phase, questionnaires for the teachers, the students and the expert evaluators are the research instrument of this research. The Computer Graphics course, among all the ICT courses, has the majority selected by the Hearing-Impaired Individuals, mostly for reasons as intensifies deaf-creativity. The analysis conducted through this research shows a positive feedback on the part of the teachers and Hearing-Impaired Students towards the interest, skills and the knowledge in learning computer courses. In terms of the E-Learning Portal E-HearMe, the teachers and the students were really satisfied with the existence of this medium.
\end{abstract}

Keywords: e-HearMe, Information Communication Technology (ICT), E-Learning, e-ICT Courses, Hearing-Impaired Individuals, Malaysia.

\section{Introduction}

Information Communication Technology (ICT) has the capacity to introduce new teaching and learning practices, as it acts as a catalyst to revolutionize the education system (Trucano, 2005). The pedagogical characteristics shows that the transfer of knowledge and information via ICT is a simple means of delivery; and via this creative use of ICT, the Creation of new knowledge is possible (Duus, 2009). Learning ICT plays a key role in the Hearing-Impaired Education Development, thus learning ICT Education online (e-learning) also empower them to develop their learning styles. In 2004, Boettcher and Conrad declared that E-Learning is learning Education conducted through the computer technology medium, where no face-to-face interaction exists as advance online learning is held in virtual learning spaces. There are various ways that E-Learning can be implemented, for example attending studying-programs or going for training-courses virtually (Savidis \& Stephanidis, 2005).

Hearing-Impaired Individuals are offered challenging, high-paying careers which are more accessible for them, by the field of ICT. As Burgstahler and Ladner stated, Computing professions are potentially open to disable individuals because of progressions in assistive technology that provide access to computers (2006). Computers being deaf-friendly are very much malleable to these Individuals, for reasons like slight management, and enhances deaf-creativity; hence ICT has opened up many career chances for them, in areas like Drawing Animation, Computer Graphics, Web Design, 
Software Development, and other computing professionals. According to Murakami et al. (2002) ICT Education is essential for them, as the visual display plays an important role in helping them realize a task. Moreover, supported visual media assistances like graphs, charts and tables are commonly utilized in computer education, as they are more visiondependent, because of their imperfection of hearing. ICT improves productivity in increasing activity for the HearingImpaired, as it empowers them to express themselves through their works like systems designers, information experts, software designers, systems analysts, etc. The constant computer technology improvement has made ICT and educational technology become increasingly more imperative in education. As mentioned before, the Hearing-Impaired Individuals greatly crave the accessibility issues in ICT courses and Web applications are vital for Hearing-Impaired Individuals. Hence, the research will focus on the evaluation of the ICT Education courses constructed from the ELearning Portal developed based on their knowledge and attitude in using the Web-Portal.

\section{Literature Review}

As O'Connor argued, E-learning produces new challenges for teaching staff, curriculum support services, disability support services and institutional administrators (O'Connor, 2002). O'Connor ,however, emphasized on necessity of teaching staff's accommodation diversity within their curriculum, by making an example of the way they design their subjects, plan the learning experiences, identify the learning materials and assess the outcomes (O'Connor, 2002). Knowledge instruments and techniques, which designate technology, play a very crucial in any present institutions, thus educational institutions like schools, colleges and universities should entirely implement ICT for the teaching and learning processes; whether to a public or private sector.

Some researchers (Bosco, 1986; Kulik et al., 1994; Parlangeli et al., 1999) claim that the use of ICT has led to a greater efficiency, through some traditional learning strategies with multimedia approaches. Debevc et al. (2007) also incorporated ICT and multimedia materials in their web-based virtual learning environment, which made it simple and powerful enough to increase the computer literacy among the Hearing-Impaired Individuals (Debevc et al., 2007). Burgstahler and Ladner, furthermore, declared that ICT Education does include Hearing-Impaired individuals to have opportunities in the industry and research internships, bridge programs between academic levels; mentor and peer support; and job improvement of educators and staff. (Burgstahler \&Ladner, 2006).

Educators have also been motivated by the quick Web evolutions given by legislation on Web accessibility to comprise this theme in Internet courses. In 2002, Sierkowski and Thatcher et al. argued that "Web accessibility defines the ability for everyone in society to have the right to use any software, hardware or any assistive technologies to understand and fully interact with the website content, regardless disability, geographical location, language barriers, or other impairing factor( Sierkowski \& Thatcher et al,2002.). According to O'Connor (2000), students with disabilities should be less a special concern and instead seen as part of the regular, diverse classroom membership, as programs need to be designed to be inclusive of everyone (O'Connor, 2000). From the legislative point of view, inclusion is supported by incorporation of the Hearing-Impaired Individuals either directly to mainstream education or to special education, in the mainstream schools or the special schools for the Hearing-Impaired. Although the Hearing-Impaired Individuals are prone to hearing, there are individuals who are rather inclusive by having high performance capabilities in specific fields like artistic and creativity, intellectuality and leadership aptitude, or in any given academic areas. (Okan \& Ispinar, 2009).

\section{Methodology}

In this research, the target audience can try the portal, including the ICT courses embedded in the portals. Not only the individuals, but also the teachers are needed to try to explore the portal, courses and every scope embedded in it. Valuable feedbacks from the teachers and the students are needed for the evaluation phase. Three schools performing the Hearing-Impaired Education Program all over Malaysia is the research location, which comprise Hearing-Impaired students from Form 4 and Form 5 of the Secondary Level as the research sample. These 3 schools were chosen, mainly because of the availability of the Computer Graphics subject taught physically in these 3 schools.

In the Evaluation phase, the ultimate purpose is to make sure the materials achieved the desired goals. In other words, this evaluation focus on the outcome of tests designed for specific domain, to judge the course's and the portal's worth at the end of the program activities (summation); and provide opportunities for feedback from the users which were identified. In this research, an assessment feedback is also incorporated into the extended part of this portal, for students to improve their learning, since they need to learn how to assess their own learning. This feedback evaluation helps students to assess the level of their knowledge towards the portal, and the ICT courses, simultaneously provide the teachers with levels of student understanding. 


\subsection{The Research Location Background}

For the evaluation stage, the selected location background was 3 secondary schools comprising Hearing Impaired Individuals of Form 4 and Form 5. These 3 schools were chosen because the Computer Graphics course were offered in their respective schools, hereafter these 3 schools becomes the research location for data collection. These 3 schools were chosen from the total number of Normal High-Schools and Technique/Vocational Schools in the Peninsular Malaysia and Sabah and Sarawak that executes the Hearing-Impaired Education.

\subsection{The Research Instruments}

The research instruments that are used to collect data are the interview sessions and the questionnaires. In this research, the interview sessions were conducted to collect data from several teachers, to generate their feedbacks and opinions on the developed 'e-HearMe' e-Learning Portal. These teachers are the academic teachers who are teaching the Computer Graphics course to the Hearing-Impaired Individuals in their respective school. For the interview sessions carried out, the samples are 2 teachers from each 3 schools; hence altogether there are 6 teachers that became the respondents for the interview sessions.

Secondly, for the Questionnaires conducted in this research, the questionnaires are distributed to the HearingImpaired Students of Form 4 and Form 5 throughout all schools in Malaysia (that are learning the Computer Graphics Course). Two techniques were used for the questionnaires by the researcher. The researcher, first, set a fixed scaling response based on the study reading, and second made the open-ended question, which gives the respondents (students) a better opportunity to answer the questions without restrictions. By doing so, the students can justify their opinion properly.

\subsection{Data Collection Procedure}

Three schools were chosen from all over Malaysia, which were involved in the performance of the Hearing-Impaired Education Program (presenting Computer Graphics Course), for the Data Collection Method. Researcher started the research from Kuala Terengganu, then headed to Negeri Sembilan, and ended with Johore. Weekdays were chosen for doing all data collection methods, and it took several months to complete the whole procedure. The completion of the questionnaires will take a number of days for the students and teachers; one day for the teachers to be interviewed, and 2 weeks of observation on each 3 schools. Since researcher does not wish to disturb the PnP (Teaching and Learning) in each school, each completed questionnaires; and each conducted interviews are obtained based on the teachers' expediency. For the 'e-HearMe' e-learning portal Intervention sessions, the lessons are performed simultaneously with the class time-table, exactly when the Computer Graphics theme is being taught for a specific session. For each school, this course approximately took around two weeks; thus all in all 6 weeks were taken to complete all 3 schools. Schools were provided with face-to-face learning approach in carrying out the lessons, whereby the students and teachers tried out the portal for the e-learning sessions.

\subsection{Data Analysis Process}

The quantitative data, as the data collection techniques, was used for the Questionnaires in the procedure of Data Analysis; same as the qualitative data for the Interviews and Observations.

For the Questionnaires Data, the Statistical Software package for the Social science module (SPSS) program was used to obtain answers to the research questions. In summary, the data of this study were analysed using the Statistic Package of Social Science (SPSS) version 11.Rresearcher will, simpler, code and score the respondents' answers using this technique.

For the Interviews and Observation Data, the Envivo program was used to analyze the answers to the research questions. This program was chosen mainly because it generates the answers forthright; therefore analyzing them into themes is easier for researcher.

\section{Result and Discussion}

To achieve the research objective which is Portal Evaluation of the e-HearMe Portal that has already been developed, there are 3 schools involved in this research. From these 3 schools, there are altogether a total of 72 students (from 3 
schools), and a total of 30 teachers (10 from each school), participated in this study. There are two focused-groups were identified. The first one is the Student Group, and second is the Teacher Group. The Student Group consists of the Hearing-Impaired Students, and The Teacher Group consists of the teachers teaching the Hearing-Impaired Students). These two groups are formed from the Questionnaires conducted.

\subsection{The Students}

The individuals participating in this study, are the Hearing-Impaired Students studying the 'Computer Graphics' course. These students are from the Higher Level Secondary School (Form 4 and Form 5), as mentioned earlier, namely Terengganu, Negeri Sembilan, and Johore. A total of 72 students of Hearing-Impaired Education took part in this study. Among them, 25were male students (34.72\%), while 47 were female students (65.28\%). This is shown clearly in Table 1.

Table 1: The Hearing-Impaired Students (Gender)

\begin{tabular}{ccccc}
\hline & & Female & Male & Total \\
\hline $\mathrm{N}$ & Valid & 25 & 47 & 72 \\
& $\%$ & 34.72 & 65.28 & 100 \\
\hline
\end{tabular}

In terms of the number of students in this study, according to the Secondary Level, 30 (41.6\%) were from Form 4, and a total of 42 (58.4\%) students were from Form 5. This is shown in Table 2.

Table 2: Hearing-Impaired Students (Secondary Level)

\begin{tabular}{ccccc}
\hline & & Form 4 & Form 5 & Total \\
\hline $\mathbf{N}$ & Valid & 30 & 42 & 72 \\
& $\%$ & 41.6 & 58.4 & 100 \\
\hline
\end{tabular}

For the race category, 45 students (62.5\%) were Malay, 25 students (34.72\%) were Chinese, 2 students (2.78\%) were Indians, as shown in Table 3.

Table 3: Hearing-Impaired Students (Race)

\begin{tabular}{cccccc}
\hline & & Malay & Chinese & Indian & Total \\
\hline $\mathbf{N}$ & Valid & 45 & 25 & 2 & 72 \\
& $\%$ & 62.5 & 34.72 & 2.78 & 100 \\
\hline
\end{tabular}

Table 4 shows the state category, 14 students (19.4\%) were respondents from Terengganu, 20 students (27.8\%) were respondents from Negeri Sembilan, and another 38 students (52.8\%) were respondents from Johore.

Table 4: Hearing-Impaired Students (State)

\begin{tabular}{cccccc}
\hline & & Terengganu & N.Sembilan & Johore & Total \\
\hline $\mathbf{N}$ & Valid & 14 & 20 & 38 & 72 \\
& $\%$ & 19.4 & 27.8 & 52.8 & 100 \\
\hline
\end{tabular}

There were altogether 3 constructs chosen for the students' questionnaire distributed to the students. These constructs were the Interface Content (14 items), the Information Content (13 items), and the Computer Graphics Content (12 items). Table 5 shows the mean and standard deviation for each constructs.

Table 5: The mean and standard deviation (for contents' interface, information, and computer graphics)

\begin{tabular}{cccc}
\hline & Interface (Antara-muka) & Information (Informasi) & Computer Graphics (ICT course) \\
\hline $\mathbf{N}$ Valid & $\mathbf{5 2}$ & $\mathbf{5 2}$ & $\mathbf{5 2}$ \\
Mean & 49.4038 & 44.5962 & 44.0577 \\
Std Deviation & 7.51798 & 7.60356 & 6.55718 \\
\hline
\end{tabular}


The Validity for the construct 'Interface' is $0.199-0.740$ which were derived from the SPSS. Table 6 shows the Reliability Statistics of Alpha Cronbach's for the construct of 'Interface'.

Table 6: The Reliability Statistic for 'Interface' (Antara-muka)

\begin{tabular}{cc}
\hline Cronbach's Alpha & N of Items \\
\hline .772 & 14 \\
\hline
\end{tabular}

The Validity for the construct 'Information Content' is $0.424-0.680$ which were derived from the SPSS. Table 7 shows the Reliability Statistics of Alpha Cronbach's for the construct of 'Information Content'.

Table 7: The Reliability Statistic for 'Information Content' (Informasi)

\begin{tabular}{cc}
\hline Cronbach's Alpha & N of Items \\
\hline .826 & 13 \\
\hline
\end{tabular}

The Validity for the construct 'Computer Graphics' is $0.371-0.718$ which were derived from the SPSS. Table 8 shows the Reliability Statistics of Alpha Cronbach's for the construct of 'Computer Graphics'.

Table 8: The Reliability Statistic for 'Computer Graphics' (ICT Course)

\begin{tabular}{cc}
\hline Cronbach's Alpha & N of Items \\
\hline .795 & 12 \\
\hline
\end{tabular}

\subsection{The Teachers}

The research sample involved are the teachers who had used the e-HearMe Portal, who are directly involved in teaching the 'Computer Graphics' course to the Hearing-Impaired Students of Form 4 and Form 5 (Higher Level Secondary School) in Terengganu, N.Sembilan, and Johore. A total of 30 teachers participated in this study, consist of 12 male teachers (40\%), and 18 female teachers (60\%), shown in Table 9.

Table 9: Teachers teaching the Hearing-Impaired (Gender)

\begin{tabular}{ccccc}
\hline & & Female & Male & Total \\
\hline $\mathbf{N}$ & Valid & 12 & 18 & 30 \\
& $\%$ & 40 & 60 & 100 \\
\hline
\end{tabular}

Table 10 shows the race category, where 26 teachers (86.7\%) were Malay respondents, 4 teachers (13.3\%) were Chinese respondents, and no Indian respondent.

Table 10: Teachers teaching the Hearing-Impaired (Race)

\begin{tabular}{cccccc}
\hline & & Malay & Chinese & Indian & Total \\
\hline $\mathbf{N}$ & Valid & 26 & 4 & 0 & 30 \\
& $\%$ & 86.7 & 13.3 & 0 & 100 \\
\hline
\end{tabular}

Table 11 shows the state category, 10 teachers (33.33\%) each was from Terengganu, Negeri Sembilan and Johore, respectively.

Table 11: Teachers teaching the Hearing-Impaired (State)

\begin{tabular}{cccccc}
\hline & & Terengganu & N.Sembilan & Johore & Total \\
\hline $\mathbf{N}$ & Valid & 10 & 10 & 10 & 30 \\
& $\%$ & 33.33 & 33.33 & 33.33 & 100 \\
\hline
\end{tabular}


There were altogether 3 constructs chosen for the students' questionnaire distributed to the students. These constructs were the Interface Content (11 items), the Information Content (11 items), and the Computer Graphics Content (9 items). Table 12 shows the mean and standard deviation for each constructs.

Table 12: The mean and standard deviation (interface, information, and CG)

\begin{tabular}{cccc}
\hline & Interface (Antara-muka) & Information (Informasi) & Computer Graphics (ICT course) \\
\hline N Valid & 30 & 30 & 30 \\
Mean & 43.0667 & 44.0000 & 36.6000 \\
Std Deviation & 7.84300 & 6.81783 & 5.58693 \\
\hline
\end{tabular}

The Validity for the construct 'Interface' is $0.302-0.932$ which were derived from the SPSS. Table 13 shows the Reliability Statistics of Alpha Cronbach's for the construct of 'Interface'.

Table 13: The Reliability Statistic for 'Interface' (Antara-muka)

\begin{tabular}{cc}
\hline Cronbach's Alpha & N of Items \\
\hline .907 & 11 \\
\hline
\end{tabular}

The Validity for the construct 'Information Content' is $0.577-0.820$ which were derived from the SPSS. Table 14 shows the Reliability Statistics of Alpha Cronbach's for the construct of 'Information Content'.

Table 14: The Reliability Statistic for 'Information Content' (Informasi)

\begin{tabular}{cc}
\hline Cronbach's Alpha & N of Items \\
\hline .900 & 11 \\
\hline
\end{tabular}

The Validity for the construct 'Computer Graphics' is $0.524-0.840$ which were derived from the SPSS. Table 15 shows the Reliability Statistics of Alpha Cronbach's for the construct of 'Computer Graphics'.

Table 15: The Reliability Statistic for 'Computer Graphics' (ICT Course)

\begin{tabular}{cc}
\hline Cronbach's Alpha & N of Items \\
\hline .883 & 9 \\
\hline
\end{tabular}

\subsection{The Evaluation Based on Knowledge}

\subsubsection{Knowledge towards the construct 'Information Content of Portal'}

For the first construct, this evaluation focused on the users' Knowledge towards the Information Content on the HearingImpaired Individuals, embedded in the Portal e-HearMe.

Table 16 obviously indications that almost $85 \%$ of the students realized how to use the E-Learning portal shown to them, since meaningful information which is related to the Hearing-Impairment can easily be comprehended in The Portal E-HearMe,.

On the question whether The Portal E-HearMe was satisfying, in the sense whether providing information fulfilling the requirements and criteria for the Hearing-Impaired students, from the 72 respondents answering this questionnaire, 60 respondents answered Strongly Agree (83.3\%), 8 respondents answered Unsure (11.1\%), and another 4 respondents answered Disagree (5.6\%). The students' claim is that understanding the Portal was easy and getting information was direct. 
Table 16: The Information Content of Portal 'e-HearMe' (students)

\begin{tabular}{|c|c|c|c|c|c|c|}
\hline & Strongly Agree & Agree & Unsure & Disagree & Strongly Disagree & Total \\
\hline N Valid & 60 & 0 & 8 & 4 & 0 & 72 \\
\hline$\%$ & 83.3 & 0 & 11.1 & 5.6 & 0 & 100 \\
\hline
\end{tabular}

Table 17 shows that almost 75\% of the teachers understood how to use the E-Learning portal demonstrated to them, as they can easily understand the meaningful information embedded in the Portal E-HearMe.

For the question whether the Portal E-HearMe was useful for the teachers teaching The Hearing-Impaired students, 22 respondents answered Agree (73.3\%), claiming that this Portal eases them to gain more information related to the Hearing-Impaired Individuals, especially in assisting them to further their education, and job prospect area. However the remaining 8 respondents answered Disagree (26.7\%), stated reasons like the Portal E-HearMe still does not have sufficient information regarding this Hearing-impaired Individuals. This is shown in Table 17.

However some concerns were raised, hoping that continuously more information would be added into the Portal eHearMe, so that it could be much more appreciated as a complete informative reliable source.

Table 17: The Information Content of the Portal 'e-HearMe' (teachers)

\begin{tabular}{|c|c|c|c|c|c|c|c|}
\hline & & Strongly Agree & Agree & Unsure & Disagree & Strongly Disagree & Total \\
\hline & Valid & 0 & 22 & 0 & 8 & 0 & 30 \\
\hline & $\%$ & 0 & 73.3 & 0 & 26.7 & 0 & 100 \\
\hline
\end{tabular}

The teachers and students gave various useful comments. For instance, comments like the information for The HearingImpaired Individuals, relating to the Job-Scopes, Further-Studies and lots more were really beneficial, not only for these individuals, but for the teachers and the parents too. In addition to this, the Teachers also pointed out that The EDictionary embedded in the E-Learning Portal e-HearMe was also really useful, especially for the Parents, as most do not really know how to converse with their own child. However, with the help of this e-Dictionary, this issue can be resolved.

\subsubsection{Knowledge towards the construct 'Computer Graphics Course'}

The second construct, this evaluation focused on the users' 'Knowledge towards the Computer Graphics Course' for the Hearing-Impaired Individuals, embedded in the E-Learning e-HearMe.

Among students who answered this questionnaire, 70 respondents answered Agree (97.2\%), nobody answered Unsure, and 2 respondents answered Disagree (2.8\%), based on the question of whether the Computer Graphics learning materials provided in the the E-Learning, e-HearMe was easy to understand.

It proves that about $97 \%$ of the students could recognize the shoen learning materials, compared to the other $3 \%$ who disagreed, as they claimed to have some problems with them. This is shown in Table 18.

Table 18: Computer Graphics Learning Materials was easy to understand (Students' View)

\begin{tabular}{|c|c|c|c|c|c|c|c|}
\hline & & Strongly Agree & Agree & Unsure & Disagree & Strongly Disagree & Total \\
\hline & Valid & 0 & 70 & 0 & 2 & 0 & 72 \\
\hline & $\%$ & 0 & 97.2 & 0 & 2.8 & 0 & 100 \\
\hline
\end{tabular}

The students state that presenting the Computer Graphics learning materials via e-learning has made it easier for them to access and obtain. They agreed that these learning materials of computer graphics are necessary to be available online, because it can be accessible anytime, anywhere.

In Table 19, for the questionnaires on the teachers' view whether the Computer Graphics Notes provided could enhance the Hearing-Impaired Students' performance in this course, 21 respondents answered 'Strongly Agree' and 'Agree' (70\%). However, the remaining 9 respondents (30\%) was 'Unsure', mainly because they still feel that The Hearing-Impaired Students does need Teachers' assistance in learning the course materials. This is shown in Table 19. 
Table 19: Computer Graphics Learning Materials does increase Students Performance in Understanding (Teachers' View)

\begin{tabular}{cccccccc}
\hline & & Strongly Agree & Agree & Unsure & Disagree & Strongly Disagree & Total \\
\hline $\mathbf{N}$ & Valid & 12 & 9 & 9 & 0 & 0 & 30 \\
& $\%$ & 40 & 30 & 30 & 0 & 0 & 100 \\
\hline
\end{tabular}

In Table 20, based on the Teachers who answered the evaluation form, all respondents Agreed (100\%), on the question of whether the Computer Graphics learning materials presented in the Portal E-HearMe does help the teachers in preparing for their Computer Graphics Teaching and Learning (PnP) class, following the syllabus set by Ministry of Education.

Table 20: Computer Graphics Learning Materials does help the Teachers for Class Preparation (Teachers' View)

\begin{tabular}{cccccccc}
\hline & & Strongly Agree & Agree & Unsure & Disagree & Strongly Disagree & Total \\
\hline $\mathbf{N}$ & Valid & 0 & 30 & 0 & 0 & 0 & 30 \\
$\%$ & 0 & 100 & 0 & 0 & 0 & 100 \\
\hline
\end{tabular}

\subsubsection{Knowledge towards the construct 'Interface (User-Friendliness)'}

The third construct, this evaluation focused on the users' 'Knowledge towards the Interface Criteria (User-Friendliness)' of the E-Learning Portal e-HearMe.

Table 21 indicates the category of Interface Criteria, on the question whether the E-Learning Portal E-HearMe was user-friendly, in that whether it provides an easy understandable navigation and links, fulfilling the requirements and criteria for the Hearing-Impaired students vision'; all Teachers answered Agree (100\%), claiming that this facilitates the users' understanding, especially the Hearing-Impaired Students, because of simplicity of the Portal, are interested in the E-Learning Portal E-HearMe, and the limited-yet-concise menu were well-suited with the Hearing-Impaired needs.

Although this was true for $100 \%$, however some suggestions were made, like they may demand to see more colorful images so as to be inserted into the E-Learning Portal E-HearMe, so that it could be much more attractive for the Hearing-Impaired. Nevertheless, due the restrictions of using Moodle, users can only select a specific template design, hence the capaability to design the layout of the E-Learning Portal E-HearMe is obstructed. This category of 'Interface (User-Friendliness)' is clearly exhibited in Table 21.

Table 21: The Interface Criteria of the E-HearMe

\begin{tabular}{cccccccc}
\hline & & Strongly Agree & Agree & Unsure & Disagree & Strongly Disagree & Total \\
\hline $\mathbf{N}$ & Valid & 15 & 15 & 0 & 0 & 0 & 30 \\
& $\%$ & 50 & 50 & 0 & 0 & 0 & 100 \\
\hline
\end{tabular}

\subsubsection{Knowledge towards the construct 'Multimedia Elements'}

The forth construct, this evaluation focused on the users' Knowledge towards the Multimedia Elements (colors, texts, images, videos), embedded in the Portal e-HearMe.

Table 22 shows the category of Multimedia Elements, on the question whether the E-Learning Portal E-HearMe was fully indicated with the multimedia elements of colours, texts, images, videos, (no audios required), aiding the interpretation of the Hearing-Impaired students; all Teachers answered Agree (100\%), claiming that this facilitates the students' understanding, especially the Hearing-Impaired Students, because of simplicity of the Portal, are interested in the E-Learning Portal E-HearMe, since the Portal does catch the vision of Hearing-Impaired.

Again, although this was true for $100 \%$, however some suggestions were made, like they may demand to see more colorful images so as to be inserted into the E-Learning Portal E-HearMe, so that it could be much more attractive for the Hearing-Impaired. Nevertheless, due the restrictions of using Moodle, users can only select a specific template design, hence the capaability to design the layout of the E-Learning Portal E-HearMe is obstructed. This category of 'Multimedia Elements' is clearly exhibited in Table 22. 
Table 22: The Multimedia Elements of the E-HearMe

\begin{tabular}{|c|c|c|c|c|c|c|}
\hline & Strongly Agree & Agree & Unsure & Disagree & Strongly Disagree & Total \\
\hline $\begin{array}{ll}\mathrm{N} & \text { Valid } \\
\end{array}$ & 4 & 26 & $\overline{0}$ & 0 & 0 & 30 \\
\hline$\%$ & 13 & 87 & 0 & 0 & 0 & 100 \\
\hline
\end{tabular}

\subsubsection{Knowledge towards the construct 'CG's Learning Materials'}

The third construct, this evaluation focused on the users' 'Attitude towards the Visual Images of the Computer Graphics Course Learning Materials' designed for the Hearing-Impaired Individuals, embedded in the Portal e-HearMe.

Most of the answers were 'Strongly Agree' and 'Agree' to the questionnaires on the students' understanding whether the Computer Graphics Notes (with more visual graphical images) provided could improve their performance in the selected course. This can be seen in Table 23.

Table 23: Computer Graphics Learning Materials (with more visual graphical images) does increase Students Performance in Understanding

\begin{tabular}{cccccccc}
\hline & & Strongly Agree & Agree & Unsure & Disagree & Strongly Disagree & Total \\
\hline $\mathbf{N}$ & Valid & 52 & 12 & 8 & 0 & 0 & 30 \\
& $\%$ & 72.2 & 16.7 & 11.1 & 0 & 0 & 100 \\
\hline
\end{tabular}

In Table 24, based on the 30 teachers who answered this questionnaire, 26 answered Yes (86.7\%), and another 4 answered No (13.3\%), on the question of whether the Computer Graphics learning materials provided in the E-Learning Portal E-HearMe does help the teachers' to understand better in preparing for their Computer Graphics Teaching and Learning (PnP) class, (with more graphical visual images) following the syllabus set by Ministry of Education.

This illustrates that almost $90 \%$ of the teachers agree that these learning materials of computer graphics needs to be available online, hence it was much easier to retrieve them wherever, compared to the other $10 \%$ who disagrees:

Table 24: Computer Graphics Learning Materials does help the Teachers for Class

\begin{tabular}{cccccccc}
\hline & & Strongly Agree & Agree & Unsure & Disagree & Strongly Disagree & Total \\
\hline $\mathbf{N}$ & Valid & 26 & 0 & 0 & 4 & 0 & 30 \\
& $\%$ & 86.7 & 0 & 0 & 13.3 & 0 & 100 \\
\hline
\end{tabular}

In terms of the ICT Courses offered (with more graphical visual images), all Teachers were really content with the Computer Graphics course exhibited in the E-Learning Portal E-HearMe, which was especially designed for the HearingImpaired Individuals. Although, more courses are added from time to time, however the teachers were really contented with the availability for the courses to be offered for these individuals.

\section{Conclusion}

In conclusion, the evaluation of results from the Students' point of view indicated that most students were pleased with the Computer Graphics Course exhibited in the E-HearMe E-Learning Portal. Having ICT courses online (E-Learning), truly helped them learn the courses with their own, since they could open it online, anytime, anywhere. Schools that do not have ICT courses can enjoy the advantages of this Portal, because now they can learn this course online. Based on the problem statement earlier, since some students do wish to have the Computer Graphics course taught in their schools, now they can learn them via this E-Learning Portal E-HearMe.

In consequence, the evaluation results from the Teachers' Perspective proved that most teachers teaching the Computer Graphics course were relieved to have an E-Learning Portal E-HearMe available and accessible to them. Results had shown positively that finally there's a medium for them to access notes, upload notes, exchange information, and an alternative way to communicate with their entire class of students, and to communicate with other teachers from the whole of Malaysia.

Lastly, in conclusion of the evaluation results from the Expert Evaluators' Perspective also proved that the E- 
Learning Portal E-HearMe was really an accomplishment for the Hearing-Impaired Individuals' needs. They powerfully believed that this E-Learning Portal E-HearMe of ICT Education really benefit the Hearing-Impaired Individuals. For now, since only 3 schools are offering Computer Graphics for the whole of Malaysia, the Expert Evaluators claimed that now other schools could also enjoy this course via E-Learning. For the schools that do not have any ICT courses offered to the students, they now can benefit this via online, therefore equal opportunities can exist for all of The Hearing-Impaired Individuals.

\section{References}

Boettcher, J.; Conrad, R. M. 2004. Faculty Guide for Moving Teaching and Learning to the Web. League for Innovation in the Community College, Laguna Hills, CA, 2004.

Bosco J. 1986. An analysis of evaluations of interactive video, Educational Technology, 25, pp. 7-16, 1986.

Burgstahler, S. and Ladner, R. 2006. An alliance to increase the participation of individuals with disabilities in computing careers. SIGACCESS Access. Comput. , 85 (Jun. 2006), 3-9.

Debevc, M. Petra Povalej, Mateja Verlič, Zoran Stjepanovič, 2007. Exploring Usability and Accessibility of an E-Learning System for Improving Computer Literacy. In Proceedings of ICTA, 2007.

Duus, H.J., 2009. A Socioeconomic Approach to the Development of E-Learning. Journal of E-learning and Education Year: 2009 Vol: 4 Issue: 5, Year 2009.

Kulik C. C. 1994. Kulik J. A.; Shwalb B. J.: The effectiveness of computer applications: a meta-analysis, Journal of Research on Computing in Education, 27, pp. 48-61, 1994

Murakami H., Minagawa H., Nishioka T, Shimizu Y., 2002. Computer education and assistive equipment for hearing impaired people. TCT Education of Disabilities, 2002 Vol. 1 (1).

O'Connor, B., 2000. E-learning and Students with Disabilities: From Outer Edge to Leading Edge", Deakin University, 2000.

Okan, Z., Ispinar, D., 2009. Gifted students' perceptions of learning English as a foreign language. Çukurova University, Faculty of Education, ELT Department, Balcalı, Adana, Turkey. 25 March, 2009.

Parlangeli O, Marchigiani E, Bagnara S, 1999. Multimedia systems in distance education: effects of usability on learning. Interacting with Computers, 12, pp. 37-49, 1999.

Savidis, A. and Stephanidis, C., 2005. Developing inclusive elearning and e-entertainment to effectively accommodate learning difficulties. In ACM SIGACCESS Accessibility and Computing, 83 (Sep. 2005), 42-54.

Sierkowski, B; Achieving Web Accessibility, 2002. SIGUCCS '02: Proceedings of 30th ACM SIGUCCS conference on User services, pages 288-291. ACM Press.

Thatcher, J, P. Bohman, M. Burks, S. L. Henry, B. Regan, S. Swierenga, and M. Urban, 2002. Constructing Accessible Web Sites; Glasshaus.

Trucano M, 2005. Knowledge maps: ICTs in education [On-line]. Washington DC: InfoDev/World Bank, 2005. 